\title{
A novel mutant acetolactate synthase gene from rice cells, which confers resistance to ALS-inhibiting herbicides
}

\author{
Kiyoshi KaWAI, Koichiro KaKu, Norihiko IzaWA, Tsutomu ShIMIzU,* Atsunori FukUdA ${ }^{\dagger}$ and \\ Yoshiyuki TANAKA ${ }^{\dagger}$ \\ Life Science Research Institute, Kumiai Chemical Industry Co., Ltd., Kikugawa-shi, Shizuoka 439-0031, Japan \\ ${ }^{\dagger}$ National Institute of Agrobiological Science, Kan-non-dai, Tsukuba-shi, Ibaragi 305-0856, Japan
}

(Received October 18, 2006; Accepted January 11, 2007)

\begin{abstract}
A two-point mutated gene of acetolactate synthase (ALS) was isolated from rice cells, which was cultured together with an ALS-inhibiting herbicide, bispyribac-sodium (BS). The mutations involved residues of tryptophan at position 548 to leucine (W548L) and serine at position 627 to isoleucine (S627I). The ALS expressed in Escherichia coli from this gene showed resistance to multiple herbicides including pyrimidinylcarboxylate (PC), sulfonylurea and imidazolinone herbicides, and showed stronger resistance to PC herbicides than to other herbicides. BS, a PC herbicide, had almost no effect on the enzyme even at $100 \mu \mathrm{M}$, which is an approximately 10,000-fold higher concentration than the concentration required for 50\% inhibition of the wild-type. The resistance level of W548L/S627I mutating ALS to BS was stronger than the additive effect predicted from the degree of resistance of each single amino acid mutated ALS. Transformed rice cells carrying this gene and a regenerated rice plant expressed resistance to BS, suggesting that this gene is useful as a selectable marker for introducing foreign traits into rice when used with PC herbicides. (C) Pesticide Science Society of Japan
\end{abstract}

Keywords: acetolactate synthase, acetohydroxyacid synthase, ALS, AHAS, pyrimidinylcarboxylates, bispyribac-sodium.

\section{Introduction}

Acetolactate synthase (ALS, EC2.2.1.6; also referred to as acetohydroxyacid synthase, AHAS) is the first common enzyme in the biosynthetic pathway to the branched-chain amino acids: valine, leucine and isoleucine. ALS is the primary target site of action for at least five structurally distinct classes of herbicides including pyrimidinylcarboxylates (PCs), sulfonylureas (SUs), imidazolinones (IMs), triazolopyrimidine sulfonamides and sulfonylaminocarbonyltriazolinones. ${ }^{1)}$

Plant ALS genes coding for their catalytic subunits were first isolated from Arabidopsis and tobacco utilizing the yeast ALS gene as a heterologous hybridization probe. ${ }^{2)}$ Since then, several plant ALS genes have been cloned and characterized. The deduced amino acid sequences are well conserved among plants. They are similar to the catalytic subunit of bacterial

\footnotetext{
* To whom correspondence should be addressed.

E-mail: t-shimizu@kumiai-chem.co.jp

Published online March 20, 2007

(C) Pesticide Science Society of Japan
}

and yeast ALSs, except for the $N$-terminal signal peptide sequences, which are required for translocation of the protein to the chloroplast. ${ }^{3)}$ The gene coding for the regulatory subunit of ALS has also been cloned and characterized. ${ }^{4)}$ The deduced amino acid of the regulatory subunit is over twice as large as that of bacteria and has two domains assumed to accept feedback inhibitors.

Plants and cultured plant cells resistant to SUs and IMs have been generated using both the conventional mutation breeding method and in vitro cell selection. ALSs from these herbicide-resistant plants have been shown to be insensitive to the herbicides. ALS genes encoding the catalytic subunit have been cloned from some of those plants, and their sequences are shown to differ from those of their wild-types. In most cases, the molecular basis for the herbicide resistance is due to a single or double amino acid change from the wild-type enzyme. ${ }^{1)}$ A herbicide-resistant ALS gene has been shown to be useful not only for the generation of transgenic plants that express resistance to the corresponding herbicides but also for introducing foreign traits into plants as a selectable marker. ${ }^{5)}$

Recently, we have obtained a mutant ALS gene from PCresistant rice cells, which confer resistance to one of the PC 


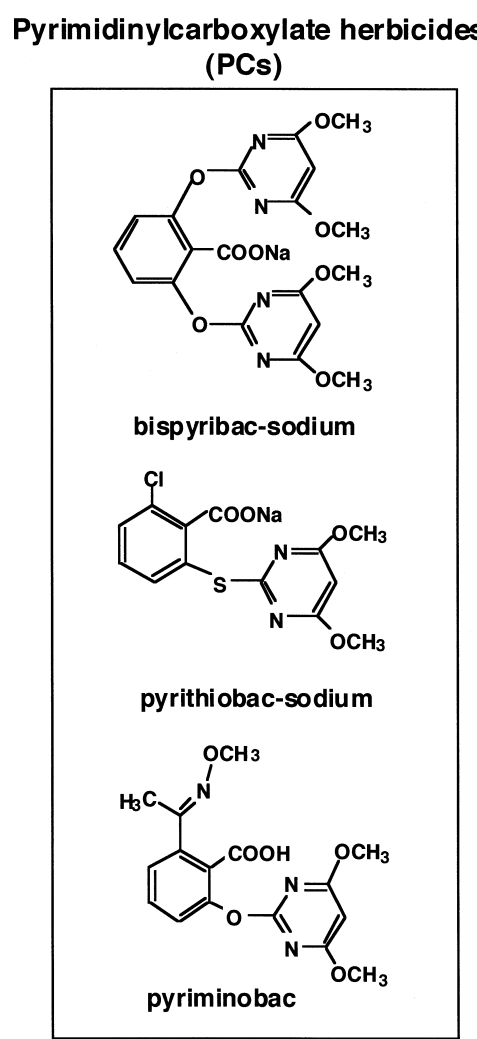

Sulfonylurea herbicides (SUs)

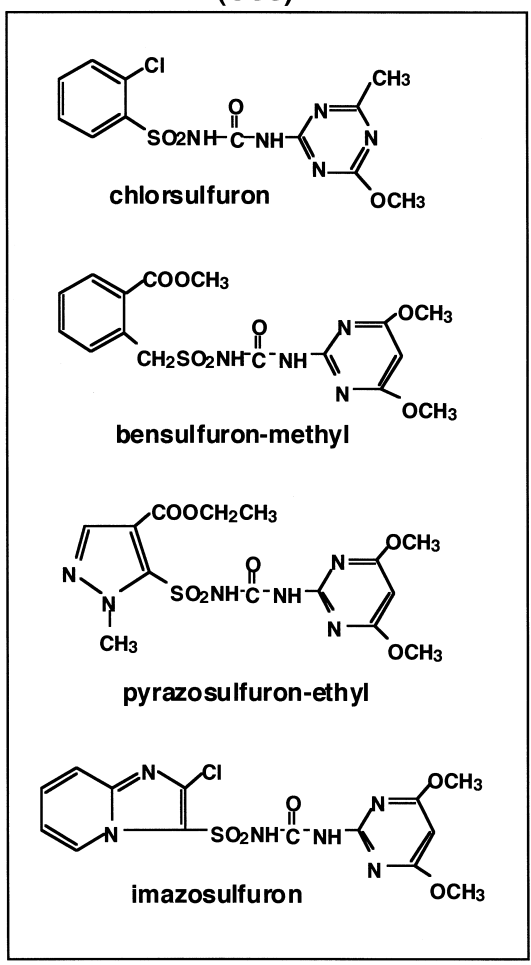

Imidazolinone herbicides (IMs)

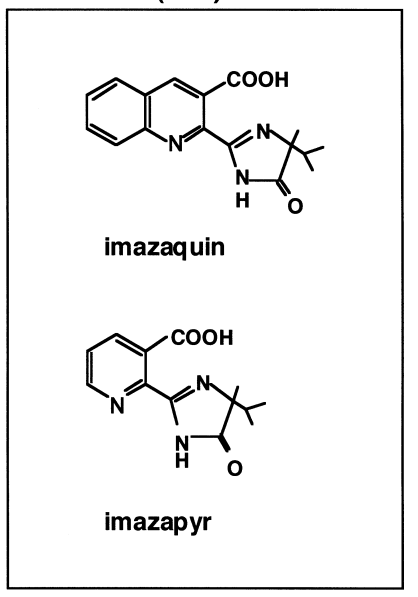

Fig. 1. ALS-inhibiting herbicides.

herbicides, bispyribac-sodium (BS). In this paper we describe the processes for isolation of the gene and show the properties of the gene and the protein expressed from the gene to use as a selectable marker for genetic transformation of plants.

\section{Materials and Methods}

\section{Compounds}

Three chemical compounds, bispyribac-sodium (BS), pyrithiobac-sodium (PS), and pyriminobac (PM), were used as pyrimidinylcarboxylate herbicides. Four chemical compounds, chlorsulfuron (CS), bensulfuron-methyl (BM), pyrazosulfuron-ethyl (PE) and imazosulfuron (IM), were used as sulfonylurea herbicides. Two chemical compounds, imazaquin (IQ) and imazapyr (IP), were used as imidazolinon herbicides (Fig. 1). These chemical compounds were synthesized by KI Chemical Research Institute Co., Ltd. (Shizuoka, Japan).

\section{Generation of rice cultured cells resistant to $B S$}

Chaff-removed rice seeds (Oryza sativa var. Kinmaze) were immersed in 70\% ethanol, and then immersed in about $5 \%$ sodium hypochloride, followed by washing several times with sterile distilled water. The seeds were then cultured in Uchimiya \& Murashige ${ }^{6)}$ solid medium under sterile conditions. The obtained calli were sub-cultured successively in a liquid medium supplemented with BS.

\section{Sensitivity of rice cells to herbicides}

Approximately $1.5 \mathrm{~g}$ (wet weight) of rice cells were transplanted to a $200 \mathrm{ml}$ of Erlenmeyer flask containing $50 \mathrm{ml}$ of Uchimiya \& Murashige liquid medium supplemented with a herbicide (BS or CS) at an appropriate concentration, followed by culturing for an appropriate period. The wet weight of the callus was measured periodically. The relative growth of calli was determined based on the wet weight of the transplanted cells.

\section{Partial purification of ALS from rice cells}

ALS protein was partially purified at below $4{ }^{\circ} \mathrm{C}$ as follows. Approximately $150 \mathrm{~g}$ of wild-type or BS-resistant cells, which were prepared by liquid culture without BS, were homogenized in three volumes of $100 \mathrm{mM}$ potassium phosphate buffer ( $\mathrm{pH} 7.5$ ) containing $20 \%(\mathrm{v} / \mathrm{v})$ glycerol, $0.5 \mathrm{mM}$ thiamin pyrophosphate (TPP), $10 \mathrm{mM}$ flavin adenine dinucleotide (FAD), $\quad 0.5 \mathrm{mM} \quad \mathrm{MgCl}_{2}, \quad$ and $15 \mathrm{~g}$ of polyvinylpolypyrrolidone (buffer-1) using Hiscotron homogenizer (Nichion-Irikakikai-Seisakujo). The homogenate was filtered through nylon gauze, and then centrifuged at $15,000 \times g$ for $20 \mathrm{~min}$. Ammonium sulfate was added to the supernatant to $50 \%$ saturation, and then allowed to stand on ice for approximately $1 \mathrm{hr}$. This homogenate was again centrifuged at $15,000 \times g$ for $20 \mathrm{~min}$, and then the precipitate was dissolved in approximately $30 \mathrm{ml}$ of $10 \mathrm{mM}$ Tri-HCl buffer (pH 7.5) containing 20\% (v/v) glycerol, $0.5 \mathrm{mM}$ TPP and 
$0.5 \mathrm{mM} \mathrm{MgCl} \mathrm{M}_{2}$ (buffer-2). The solution was again centrifuged at $15,000 \times g$ for $20 \mathrm{~min}$, and then the supernatant was applied to a Sephadex G-25 (GE Healthcare Bio-Sciences KK) column. Approximately $40 \mathrm{ml}$ of the pass-through fraction was collected as a crude enzyme solution. The protein concentration of this solution was measured by the Bradford method. This solution was then filtered through a Whatman $25 \mathrm{~mm}$ GD/X Sterile Syringe Filter, and applied to three verticallyconnected HiTrap Q columns (GE Healthcare Bio-Sciences KK) using an FPLC (GE Healthcare Bio-Sciences KK). After proteins were adsorbed, the columns were washed with buffer-2. The adsorbed protein was then eluted using $150 \mathrm{ml}$ of buffer- 2 with a linear concentration gradient ( 0 to $0.4 \mathrm{M}$ ) of $\mathrm{KCl}$. The eluate was fractionated into $5 \mathrm{ml}$ each in test tubes including $0.5 \mathrm{ml}$ of buffer- 2 containing $20 \mathrm{mM}$ sodium pyruvate to stabilize ALS.

\section{Assay of ALS and direct acetoin forming activity}

ALS activity was measured as follows. A reaction mixture $(1 \mathrm{ml})$ was prepared by mixing an enzyme solution with a solution comprising $20 \mathrm{mM}$ sodium pyruvate, $0.5 \mathrm{mM}$ TPP, $0.5 \mathrm{mM} \mathrm{MgCl}_{2}, 10 \mathrm{mM}$ FAD and $20 \mathrm{mM}$ potassium phosphate buffer ( $\mathrm{pH}$ 7.5). After the enzyme solution was added, the reaction was conducted at $30^{\circ} \mathrm{C}$ for 40 to $60 \mathrm{~min}$. The reaction was then stopped by the addition of $0.1 \mathrm{ml}$ of $6 \mathrm{~N}$ sulfuric acid (for the ALS activity) or $0.25 \mathrm{~N}$ sodium hydroxide (for direct acetoin-forming activity). The mixture was incubated at $60^{\circ} \mathrm{C}$ for $10 \mathrm{~min}$, thereby converting acetolactate to acetoin. Then, $1 \mathrm{ml}$ of $0.5 \%(\mathrm{w} / \mathrm{v})$ creatine and $1 \mathrm{ml}$ of $5 \%(\mathrm{w} / \mathrm{v}) \alpha$-naphthol dissolved in $2.5 \mathrm{~N}$ sodium hydroxide were added to the mixture, followed by incubation at $60^{\circ} \mathrm{C}$ for $10 \mathrm{~min}$. Acetoin was then quantified by color comparison of the mixture at absorbance of $525 \mathrm{~nm}$. Reaction-time zero was used as the control.

\section{Cloning of the wild-type and the mutant ALS gene} A rice partial cDNA clone (accession No. C72411), which was an ALS homolog-retaining plasmid, pBluescript II SK+ with an $1.6 \mathrm{~kb}$ insert DNA, was obtained from the MAFF DNA bank. The entire nucleotide sequence of the insert was determined with an ABI PRISM 310 genetic analyzer. Its homology to the nucleotide sequence of corn was $84.7 \%$, revealing that the insert cDNA was a partial cDNA of the rice ALS gene. Thus, the insert DNA was digested with Sal I and Not I, and used as a probe for cloning ALS genes. The probe DNA was labeled by both the RI and non-RI method. RI labeling of the probe was performed using a BcaBEST DNA labeling kit (Takara Shuzo Co., Ltd.). Non-RI labeling of the probe was performed by DNA labeling reagent (peroxidase) and glutaraldehyde, which are provided in an ECL direct DNA/RNA labeling and detection system (GE Healthcare Bio-Sciences KK). Messenger RNAs were prepared by the standard method from approximately $200 \mathrm{~g}$ of wild-type and BS-resistant rice cells using an oligo dT cellulose (GE Healthcare Bio-Sci- ences KK) column. Complementary DNAs were synthesized using $2 \mathrm{mg}$ of mRNAs, so that cDNA $\lambda$ phage libraries derived from wild-type and BS-resistant cells were constructed. ALS cDNAs were isolated by the standard method and cloned into pBluescript II SK + that had been digested with Eco RI. Escherichia coli strain JM 109 was transformed with this plasmid. The obtained transformants were subjected to liquid culture, and then plasmids were prepared by the standard method. The nucleotide sequences of ALS cDNAs in the plasmids were determined with an ABI PRISM 310 genetic analyzer by primer walking.

\section{Expression, preparation and purification of recombi- nant ALSs}

The pBluescript II SK+ retaining ALS cDNA was digested with Eco RI. cDNAs of wild-type and mutated ALS genes were incorporated into Eco RI sites of pGEX 2T and pGEX 4T-3 (or pGEX 6P-1) vectors respectively. E. coli strain JM 105 was transformed with these vectors. The colonies obtained by transformation were subjected to liquid culture, then plasmids were extracted, and the orientation of the insert DNA was confirmed by the restriction enzyme cleavage pattern and sequencing. Clones, where the orientation of the insert DNA was as expected, were selected, and then cultured in an LB medium containing ampicillin. Using $1 \mathrm{ml}$ of the preculture solution, culturing was performed in $50 \mathrm{ml}$ or $250 \mathrm{ml}$ of an LB medium containing ampicillin. After culturing overnight, $1 \mathrm{mM}$ IPTG was added, and then GST-fused protein was induced for 3 to $4 \mathrm{hr}$. A pellet of the transformed $E$. coli was suspended in $2.5 \mathrm{ml}$ of potassium phosphate buffer $\mathrm{pH} 7.5$ containing $30 \%$ glycerol and $0.5 \mathrm{mM} \mathrm{MgCl}_{2}$. The suspension was subjected to ultrasonication (Heat Systems-Ultrasonics, Sonicator W-225R), and subjected to centrifugation at $15,000 \times g$ for $20 \mathrm{~min}$, thereby obtaining the supernatant as a crude enzyme solution. GST-fused ALS protein was purified from the crude enzyme solution by the following method. The crude enzyme solution $(12.5 \mathrm{ml})$ that had been prepared from the pellet (obtained from $250 \mathrm{ml}$ of the culture solution) was applied to a glutathione sepharose 4B affinity column (1 $\mathrm{ml}$ of bed volume) (GE Healthcare Bio-Sciences KK) pre-equilibrated with $10 \mathrm{ml}$ of phosphate-buffered saline (PBS). The column was washed with $10 \mathrm{ml}$ of PBS, and then the adsorbed GST-ALS was eluted (4 times) with $2 \mathrm{ml}$ of $10 \mathrm{mM}$ glutathione solution. GST and ALS activities of each fraction were measured, and fractions with high activity were collected. GST activity was measured by rate assay using 1chloro-2,4-dinitrobenzene as a substrate. The purified ALS free from GST was prepared by protease (thrombin or prescission protease) treatment.

8. Preparation of protein expression vectors retaining single point mutated ALS cDNAs, and expression of recombinant $A L S S$

The mutant ALS gene having the W548L single mutation was 
prepared as follows. First, PCR was performed using a sense primer named ALS-Rsp6 (5'-CATCACCAACCACCTCTT$\left.3^{\prime}\right)$ and an anti-sense primer named ALS-RspF (5'-ACACGGACTGCAGGAATA-3'), and using pBluescript II SK + retaining the double-point mutant ALS gene as a template, thereby amplifying a DNA fragment having the W548L mutation but no S627I mutation. Meanwhile, a DNA fragment containing a region encoding serine at position 627 was amplified using a sense primer named ALS-RspE (5'-TTACAAGGCGAATAGGGC-3' ${ }^{\prime}$ ) and an M13R anti-sense primer (5'-GGAAACAGCTATGACCATG-3') and using pBluescript II $\mathrm{SK}+$ retaining the wild-type ALS gene as a template. Next, a large DNA fragment was obtained from the two DNA fragments by linking them using the overlapping extension method. The obtained DNA fragment was digested with Acc I and Eco RI, thereby obtaining an Acc I-Eco RI fragment. After pGEX 2T plasmid containing the incorporated wildtype ALS gene (pGEX 2T-wALS) was digested at the Acc I site, partial digestion was performed with $E c o$ RI at $37^{\circ} \mathrm{C}$ for $1 \mathrm{~min}$, thereby obtaining a partial fragment of pGEX $2 \mathrm{~T}$ plasmid. Then, ligation of the Acc I-Eco RI fragment and the partial fragment of pGEX $2 \mathrm{~T}$ plasmid resulted in a plasmid having the W548L mutant ALS gene. On the other hand, the mutant ALS gene having only S627I was obtained according to the method by which the W548L mutant ALS gene was prepared; that is, the S627I mutant ALS gene could be obtained in the same manner as employed for the above W548L mutant ALS gene except that ALS-RspE and M13R were used as primers in PCR performed using pBluescript II SK+ as a template, and ALS-Rsp6 and ALS-RspF were used as primers in PCR performed using pBluescript II SK+ retaining the wild-type ALS gene as a template. A plasmid having the W548L mutant ALS gene and a plasmid having the S627I mutant ALS gene were separately transferred into $E$. coli strain JM109. Full sequencing of the ALS gene was performed for the obtained $E$. coli colonies, so that the singlepoint mutation of W548L mutation and that of S627I mutation could be confirmed.

\section{Sensitivity of ALS to herbicides}

The sensitivity of the partially purified ALSs from rice cells and the recombinant ALSs expressed in E. coli to ALS-inhibiting herbicides was examined as follows. Solutions containing the herbicides at certain concentrations (BS and PS were aqueous solutions and the others were acetone solutions) were added to the reaction mixture before addition of the ALS protein. The final concentration of acetone was $1 \%$. Since a recombinant ALS expressed in E. coli is unsusceptible to valine, ${ }^{7)}$ an assay using a crude preparation of the GST-ALS was performed under conditions in which the ALS activity derived from $E$. coli was inhibited with $10 \mathrm{mM}$ valine.

\section{Transformation of rice with the double mutated ALS cDNA}

The W548L/S627I mutant ALS cDNA was incorporated into a binary vector, pMLH7133, ${ }^{8}$ which was developed for transformation of a rice plant, thereby obtaining pMLH7133-ALS. The obtained pMLH7133-ALS was transferred into E. coli strain JM109. The resulting single colony was subjected to liquid culture, and then a plasmid was prepared by the alkali SDS method. This binary vector was introduced into cells of Rhizobium radiobactor (Agrobacterium tumefaciens) EHA 105 by electroporation.

Calli, which had been induced from seeds (cv. Nipponbare) and pre-cultured in an N6D medium, were infected by Agrobacteria harboring pMLH 7133-ALS with the standard method. The calli were placed on an N6D solid medium containing $500 \mathrm{mg} / \mathrm{l}$ carbenicillin and $50 \mathrm{mg} / \mathrm{l}$ hygromycin. Hygromycin-selected calli were transplanted on re-differentiation media followed by transplantation onto hormone-free media. When regenerated plants spread over the Petri dish, the plants were potted into culture soil. Transformed rice plants were appropriately selected, and $1 \mathrm{~kg}$ a.i./ha BS supplemented with $0.2 \%$ surfactant $\mathrm{K}$ was sprayed over the leaves and stems. Growth was surveyed 40 days after spraying. Some of the calli before differentiation were sub-cultured on solid media, followed by liquid culture, and then BS sensitivity was examined. Nucleotide sequences of selected calli and re-generated plants were analyzed as follows. Genomic DNA was prepared from calli and plants using a DNeasy Plant Kit (QIAGEN Inc.). PCR was then performed with a sense primer (31-4: 5'-AGGTGTCACAGTTGTTG-3') and an anti-sense primer (4-83-3: 5'-GCTTTGCCAACATACAG-3') that flank the double-point mutated portion using genomic DNA as a template. The amplified DNA fragment was purified, and then the nucleotide sequence was analyzed with a sense primer, 31-4, and an anti-sense primer, ALS-Rsp2 (5'-AGTCCTGCCATCACCATCCAG-3').

\section{Results}

\section{Generation of rice (cv. Kinmaze) cultured cells resist- ant to $B S$}

After approximately two months of cultivation with $1 \mu \mathrm{M}$ of $\mathrm{BS}$, non-discolored cells were obtained from culture cells, most of which had died and become discolored to brown. These cells were isolated and sub-cultured, so that a cell line that could proliferate in the presence of $2 \mu \mathrm{M}$ of BS was obtained. This cell line was subsequently cultured while elevating the concentration of BS. Consequently, a cell line that grew in the presence of $100 \mu \mathrm{M}$ BS was obtained. The sensitivity of the cell line to ALS-inhibiting herbicides was then compared to the wild-type. The growth of wild-type cells was not inhibited by $1 \mathrm{nM} \mathrm{BS}$, but was inhibited by $10 \mathrm{nM}$ or more BS; however, that of the BS-resistant cell line was hardly affected even by $10 \mu \mathrm{M}$ BS. On the other hand, the growth of the wild-type was inhibited by an SU herbicide, CS to almost 

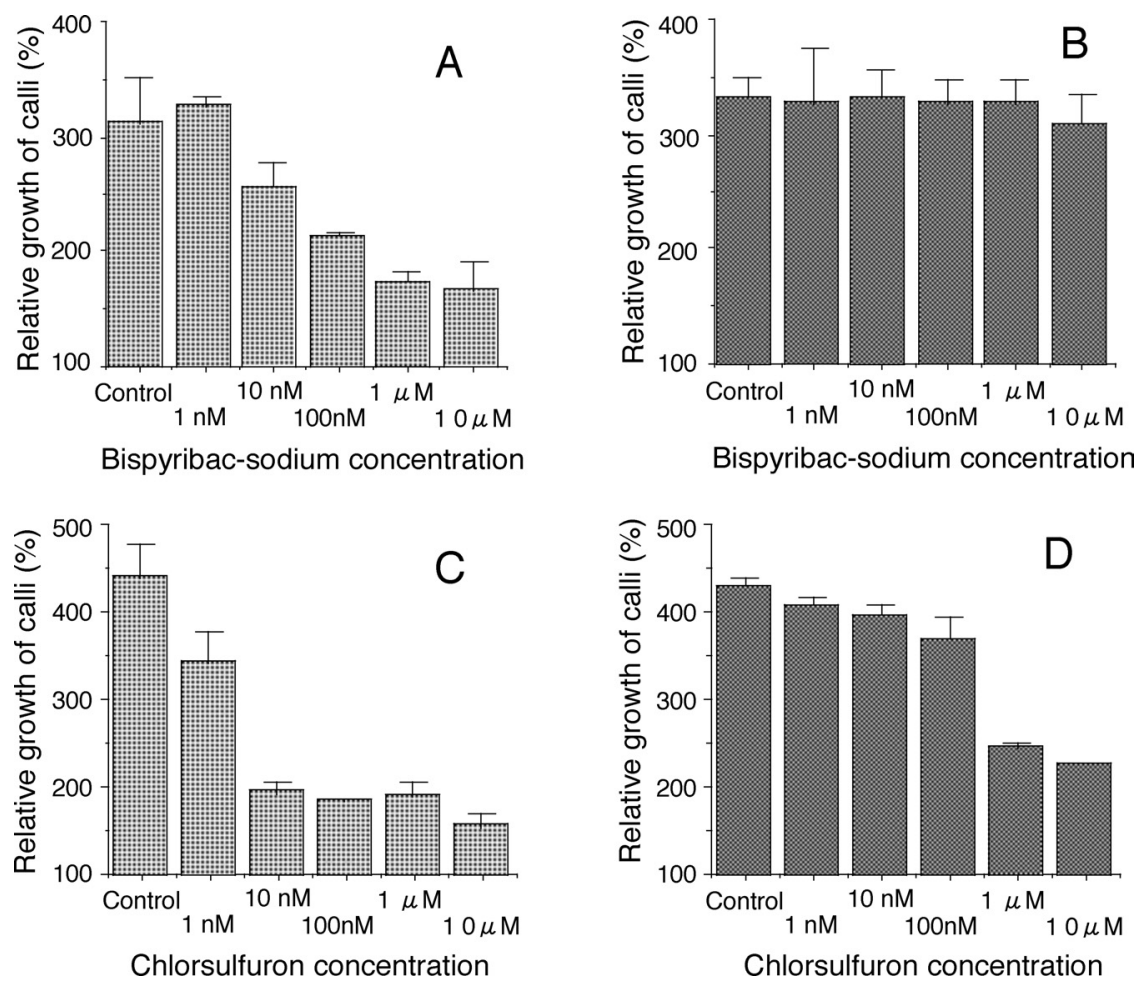

Fig. 2. Sensitivity of rice cells to bispyribac-sodium and chlorsulfuron. A and C: wild-type; B and D: mutant.

the same extent as BS, while that of the resistant cell line was strongly inhibited by $1 \mu \mathrm{M} \mathrm{CS}$ (Fig. 2). These results showed that the BS-resistant cell line possessed resistance specific to BS.

\section{Herbicide sensitivity of ALS partially purified from BS-resistant cells}

Two ALS activity peaks were detected by negative ion exchange FPLC of the crude enzyme preparation from BS-resistant cells (Fig. 3). It was found that a fraction eluted earlier, which expressed no direct acetoin-forming activity, corre-

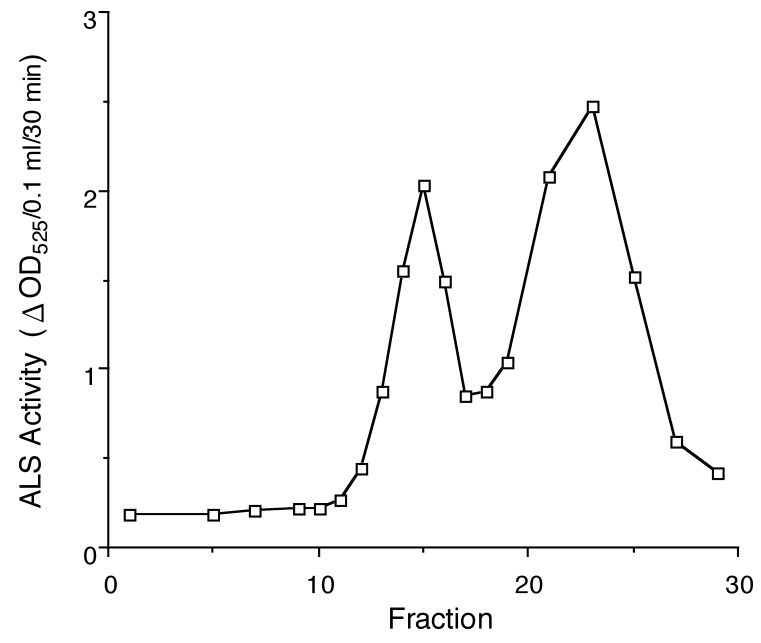

Fig. 3. Chromatogram of negative ion exchange chromatography of the crude enzyme preparation from BS-resistant rice cells. sponded to the mutant ALS protein. The wild-type ALS protein was also partially purified by the same method. Using these mutant and wild-type ALS proteins, sensitivities to BS, CS and IQ were examined. The mutant ALS showed a relatively high ALS activity even in the presence of herbicides, when compared to the wild-type ALS. In particular, the most significant difference between the mutant and the wild-type ALS was the sensitivity to BS, indicating that the mutant ALS possessed especially high resistance to BS (Table 1).

\section{Cloning of wild-type and mutant ALS cDNAs}

One full-length ALS cDNA, of which the translational region was 3 nucleotides longer than the initiation codon, was isolated from a cDNA library of wild-type rice cells. Two kinds of full-length ALS cDNA, of which the non-translation region was 47 nucleotides and 31 nucleotides longer than the initia-

Table 1. Sensitivity of ALSs from rice calli to ALS-inhibiting herbicides

\begin{tabular}{lcccc}
\hline \multirow{2}{*}{ Herbicide } & \multicolumn{2}{c}{$\mathrm{I}_{50}(\mathrm{nM})^{a)}$} & & RS Ratio \\
\cline { 2 - 3 } \cline { 5 - 5 } & Wild & Mutant & & Mutant/Wild \\
\hline Bispyribac-sodium (BS) & 5.63 & 421 & & 74.8 \\
Chlorsulfuron (CS) & 17.3 & 92.8 & & 5.36 \\
Imazaquin (IQ) & 1480 & 16700 & & 11.3 \\
\hline
\end{tabular}

a) Concentration required for $50 \%$ inhinition. ${ }^{\text {b) }} \mathrm{RS}$ ratio $=$ $\mathrm{I}_{50}$ (mutant) $/ \mathrm{I}_{50}$ (wild type). 


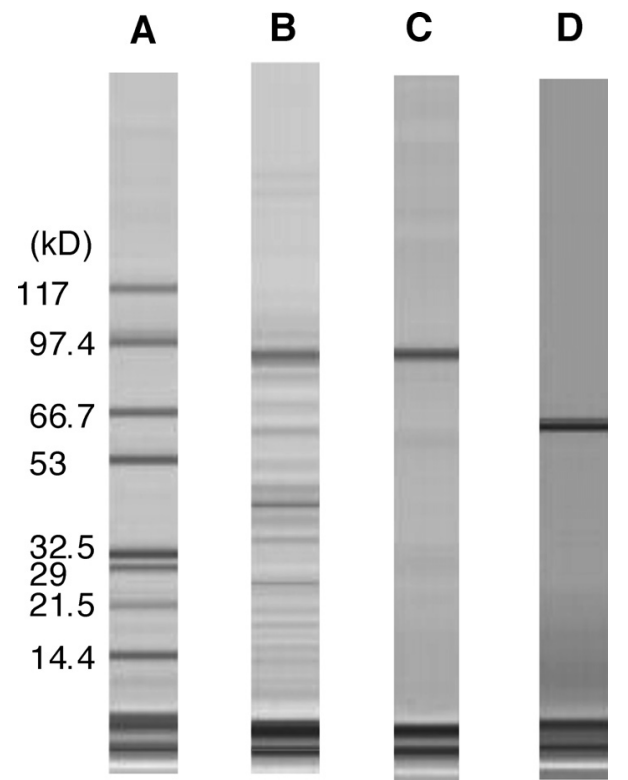

Fig. 4. Gel images of electrophoresis with the Agilent Bio-analyzer. A, molecular markers; B, crude enzyme preparation; C, purified GST-ALS; D, purified GST free ALS.

tion codon, were isolated from a cDNA library of BS-resistant cells (accession numbers: AB049822 and AB049823). One of these ALS cDNAs had an identical sequence to that derived from wild-type cells; thus this was considered to encode the wild-type ALS protein. The deduced amino acid sequence of this cDNA is highly conserved compared with corn (accession number: X63553 and X63554) ${ }^{9)}$ and barley (accession number, AF059600/partial cDNA). The other ALS cDNA derived from BS-resistant cells was assumed to encode a mutant ALS. The mutations of this cDNA involved residues of tryptophan at position 548 to leucine (W548L) and serine at position 627 to isoleucine (S627I).

\section{Expression of ALS proteins and their sensitivity to her- bicides}

The crude enzyme preparation from $E$. coli expressing the GST-fused wild-type ALS or the double-mutated ALS showed specific activity approximately 3- to 4-fold higher than that from the control containing no plasmid. The GST-fused ALS proteins expressed in E. coli were purified by GST affinity column chromatography. ALSs were prepared by protease treatment and the molecular weight of the ALS free from GST was evaluated using an Agilent bioanalyzer (Fig. 4). The GST-fused ALS from the double-mutated ALS cDNA expressed a similar specific activity to that of the wild-type (data not shown). The GST-fused ALS from the wild-type ALS cDNA showed similar sensitivity to ALS-inhibiting herbicides compared with that prepared from a natural source. ${ }^{10)}$ On the other hand, the GST-fused ALS from the mutant ALS cDNA expressed resistance to different classes of ALS-inhibiting herbicides including PCs: BS, PS, PM, SUs: CS, BM, PE, IS,
Table 2. Sensitivity of recombinant ALSs to ALS-inhibiting herbicides

\begin{tabular}{|c|c|c|c|c|}
\hline \multirow{2}{*}{ Class } & \multirow{2}{*}{ Herbicide } & \multicolumn{2}{|c|}{$\mathrm{I}_{50}(\mathrm{nM})^{a)}$} & \multirow{2}{*}{$\frac{\text { RS Ratio }^{b)}}{\text { Mutant/Wild }}$} \\
\hline & & Wild & Mutant & \\
\hline \multirow[t]{3}{*}{$\mathrm{PC}$} & Bispyribac-sodium & 6.3 & $0.3 \%{ }^{c)}$ & $>16000$ \\
\hline & Pyrithiobac-sodium & 11 & $32 \%{ }^{c)}$ & $>9100$ \\
\hline & Pyriminobac & 8.0 & $13 \%^{c)}$ & $>13000$ \\
\hline \multirow[t]{4}{*}{ SU } & Chlorsulfuron & 13 & 2600 & 200 \\
\hline & Bensulfuron-methyl & 7.0 & $22 \%^{c}$ & $>14000$ \\
\hline & Pyrazosulfuron-ethyl & 20 & 50000 & 2500 \\
\hline & Imazosulfuron & 25 & 65000 & 2600 \\
\hline \multirow[t]{2}{*}{$\mathrm{IM}$} & Imazaquin & 2200 & $12 \%^{c)}$ & $>45$ \\
\hline & Imazapyr & 9600 & $27 \%^{c)}$ & $>10$ \\
\hline
\end{tabular}

a) Concentration required for $50 \%$ inhibition. ${ }^{b)} \mathrm{RS}$ ratio $=\mathrm{I}_{50}$ (mutant) $/ \mathrm{I}_{50}$ (wild-type). ${ }^{c)}$ Inhibition percentage by $0.1 \mathrm{mM}$ of compounds.

and IMs: IQ, IP (Table 2), but it showed stronger resistance to BS than to the others. BS had no effect on the enzyme even at $100 \mu \mathrm{M}$, which is an approximately 10,000 -fold higher concentration than that required for $50 \%$ inhibition of the wildtype enzyme (Fig. 5). Purified GST-fused ALSs and purified ALSs showed herbicide sensitivities similar to those of crude enzymes in the presence of $10 \mathrm{mM}$ valine (data not shown).

\section{Expression of single-point mutated ALSS and their sensitivity to herbicides}

ALS cDNAs possessing each single mutation were generated by PCR and the overlapping extension PCR using the wildtype and the double-mutated ALS cDNAs as templates. Each GST-fused ALS protein was expressed in E. coli, and its sensitivity to the herbicides was examined. Each single mutation of W548L and S627I in the ALS conferred resistance to BS,

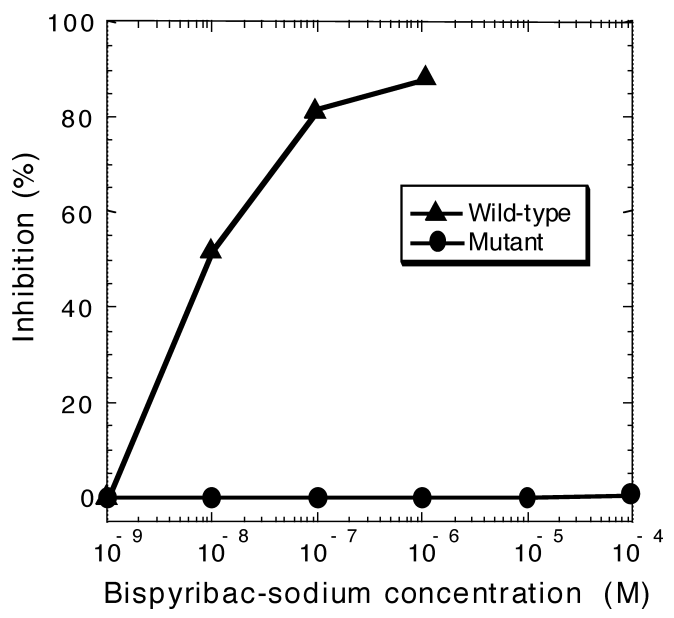

Fig. 5. Sensitivity of recombinant ALSs to bispyribac-sodium. 


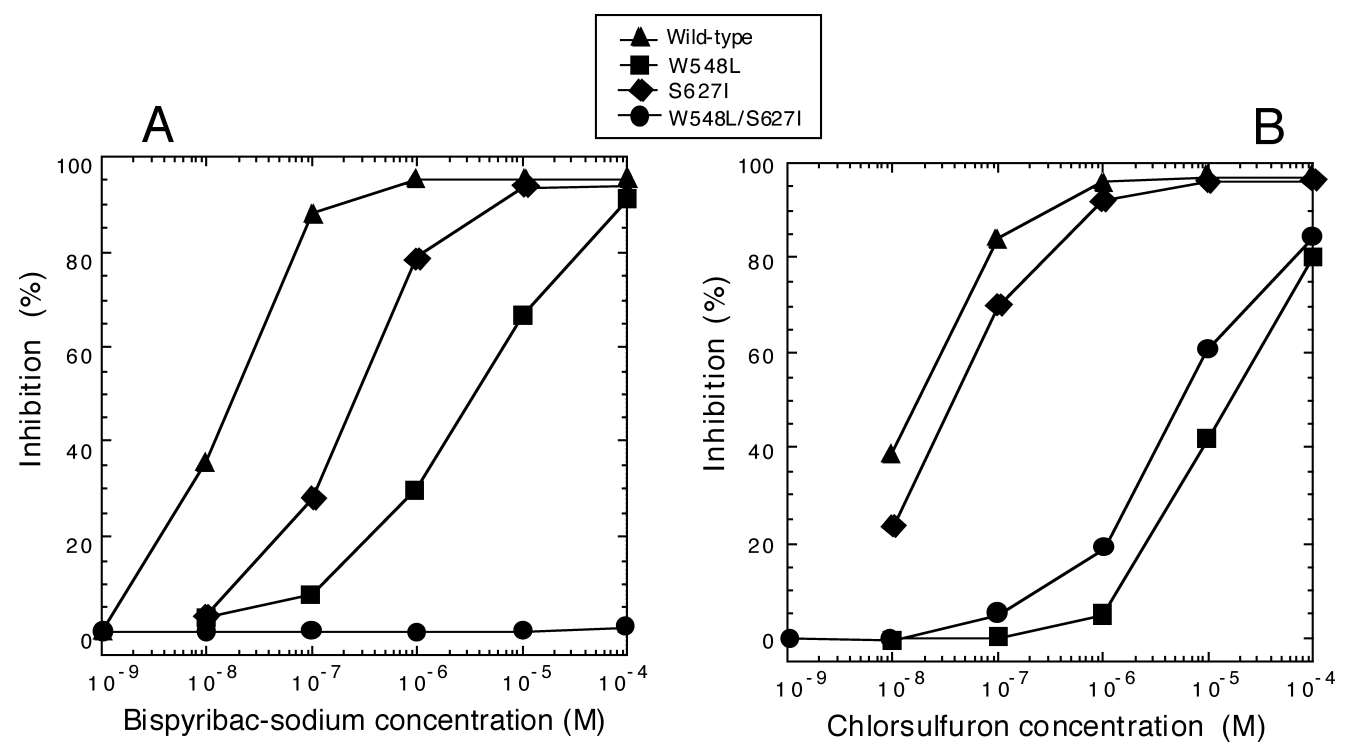

Fig. 6. Comparison of sensitivity of recombinant ALSs to bispyribac-sodium and chlorsulfuron.

and the degree of resistance was higher in W548L than in S627I. The level of resistance to herbicides among these single-mutated ALSs was all shown to be lower than that of the double-mutated ALS (Fig. 6). The W548L mutation alone conferred resistance to $\mathrm{CS}$, while the S627I mutation alone conferred no obvious resistance to this herbicide. A comparison of the degree of resistance to CS between the W548L single mutant and the W548L/S627I double mutant revealed that they shared the same degree of resistance (Fig. 6). Therefore, the S627I mutation, which was first found in this study, was shown to drastically enhance especially BS resistance when it was introduced to an ALS gene carrying the W548L mutation.

\section{Transformation of rice with the double mutated ALS}

Rice cells (cv. Nippon-bare) were transformed with the double-mutated ALS cDNA in the binary vector, pMLH 7133, and then the introduced cDNA of transformed cells, which were selected by hygromycin pressure, was analyzed. Heterologous sequences of the wild-type and the mutant were found in the nucleotide sequence of the ALS in the genomic DNA from the cells, indicating that the double-mutated ALS cDNA was incorporated into the genome. These cells grew well in the presence of $10 \mu \mathrm{M}$ BS as well as cells from which the double-mutated ALS cDNA was isolated (data not shown). Of 80 transformed rice plants regenerated from cells, 27 plants grew normally. These plants were shown to possess the mutant gene as indicated in the transformed cells. At the 5th leaf stage, four of these 27 plants containing the mutant ALS gene were appropriately selected, and $1 \mathrm{~kg}$ a.i./ha BS supplemented with $0.2 \%$ surfactant was sprayed over the leaves and stems. One of these plants grew normally, suggesting that the plant was highly resistant to BS (Fig. 7).

\section{Discussion}

Mutations in the ALS of crops and Arabidopsis that have been reported to confer resistance to ALS-inhibiting herbicides are described in Table 3 using the rice ALS number shown in this paper. The most commonly encountered muta-

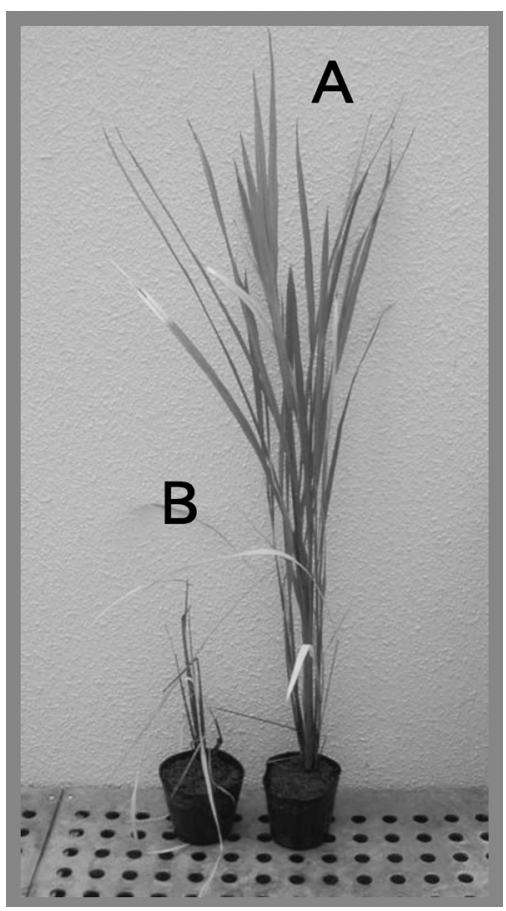

Fig. 7. Photograph showing bispyribac-sodium sensitivity of rice plants transformed with ALS genes (40 days after treatment of bispyribac-sodium at $1 \mathrm{~kg}$ a.i./ha). A, Rice plant transformed with the mutant ALS gene. B, Rice plant transformed with the wild-type ALS gene. 
Table 3. Mutations in ALS conferring resistance to ALS-inhibiting herbicides

\begin{tabular}{|c|c|c|c|}
\hline Plant species & Mutation $^{a}$ ) & Method $^{b)}$ & Selection \\
\hline Zea mays & A96T & $\mathrm{CMB}$ & Imidazolinone \\
\hline Beta vulgaris & A96T & $\mathrm{SCM}$ & Imidazolinone \\
\hline Arabidopsis thaliana & A96V & SDM & \\
\hline Arabidopsis thaliana & M98E & SDM & \\
\hline Arabidopsis thaliana & M98I & SDM & \\
\hline Arabidopsis thaliana & M98H & SDM & \\
\hline Arabidopsis thaliana & P171S & $\mathrm{CMB}$ & Sulfonylurea \\
\hline Nicotiana tabacum & P171Q & SCM & Sulfonylurea \\
\hline Nicotiana tabacum & P171A & SCM & Sulfonylurea \\
\hline Nicotiana tabacum & P171S & SCM & Sulfonylurea \\
\hline Beta vulgaris & P171S & SCM & Sulfonylurea \\
\hline Brassica napus & P171S & SDM & \\
\hline Arabidopsis thaliana & P171deletion & SDM & \\
\hline Arabidopsis thaliana & R173A & SDM & \\
\hline Arabidopsis thaliana & $\mathrm{R} 173 \mathrm{E}$ & SDM & \\
\hline Arabidopsis thaliana & F180R & SDM & \\
\hline Zea mays & W548L & CMB & Imidazolinone \\
\hline Nicotiana tabacum & W548L & SCM & Sulfonylurea \\
\hline Brassica napus & W548L & $\mathrm{SCM}$ & Sulfonylurea \\
\hline Oryza sativa & W548L & SCM & Pyrimidinylcarboxylate \\
\hline Gossypium hirsutum & W548S & $\mathrm{SCM}$ & Sulfonylurea \\
\hline Gossypium hirsutum & W548C & SCM & Sulfonylurea \\
\hline Arabidopsis thaliana & W548L & SDM & \\
\hline Nicotiana tabacum & W548F & SDM & \\
\hline Arabidopsis thaliana & W548S & SDM & \\
\hline Arabidopsis thaliana & W548deletion & SDM & \\
\hline Zea mays & S627D & $\mathrm{CMB}$ & Imidazolinone \\
\hline Arabidopsis thaliana & S627N & $\mathrm{SCM} / \mathrm{SDM}$ & Imidazolinone \\
\hline Zea mays & S627N & SCM & Imidazolinone \\
\hline Oryza sativa & S627I & $\mathrm{SCM}$ & Pyrimidinylcarboxylate \\
\hline Arabidopsis thaliana & S627T & SDM & \\
\hline Arabidopsis thaliana & S627F & SDM & \\
\hline Arabidopsis thaliana & S627deletion & SDM & \\
\hline
\end{tabular}

${ }^{a)}$ Amino acids are described by one letters. ${ }^{b)}$ Mutated ALS were obtained through conventional mutation breeding (CMB), somatic cell mutation (SCM) or site-directed mutagenesis (SDM).

tions involve the residues of alanine at position 96 (A96), proline at position 171 (P171), tryptophan at position 548 (W548) and serine at position 627 (S627). The mutation of W548L was first isolated together with the mutation of $\mathrm{P} 171 \mathrm{~A}$ in tobacco ${ }^{2)}$ through selection by the SU. Since then, this mutation has been found in corn ${ }^{11)}$ and canola. ${ }^{12)}$ It was first shown that this mutation confers resistance to both SUs and IMs using the mutated gene generated by site-directed mutagenesis. ${ }^{13)}$ This mutation confers resistance to different classes of ALS-inhibiting herbicides. At this position, other amino acid substitutions, W548C and W548S, have been found in cotton. ${ }^{14)}$

On the other hand, a mutation of S627 was first found in IM-resistant Arabidopsis. ${ }^{15)}$ In contrast to W584L, the mutation of S627N confers resistance to the IM, but not to the SU. ${ }^{16)}$ This mutation as well as a different amino acid change, S627D, has been reported in IM-resistant corn. ${ }^{17,18)}$ The mutations at this position leading to S627A, S627N, S627T and 
S627F have been studied in Arabidopsis by site-directed mutagenesis. ${ }^{19)}$ Based on the sensitivity of mutated enzymes expressed in E. coli, it has been suggested that the size of the amino acid chain at this position determines resistance.

Regarding double mutations, three combinations have been reported in addition to the double mutation of the $\mathrm{P} 171 \mathrm{~A} / \mathrm{W} 548 \mathrm{~L}$ pair found in tobacco as described above; $\mathrm{P} 171 \mathrm{~S} / \mathrm{S} 627 \mathrm{~N}$ in Arabidopsis, ${ }^{20,21)} \mathrm{A} 96 \mathrm{~T} / \mathrm{P} 171 \mathrm{~S}$ in sugar beets $^{22)}$ and A96T/S627T in tobacco. ${ }^{23)}$

SU-resistant weeds were first found in kochia and prickly lettuce in the field with the repeated use of CS. Since then, many weed species have developed resistance to SUs and IMs. ${ }^{24)}$ Weeds possessing the mutated ALS at the P171 position were found in fields with the repeated use of the SU, whereas that of S627 was found with the use of the IM. In addition, a mutation at the W548 position was found in weeds through selection by both IMs and SUs. These mutation patterns raised by herbicide applications are very similar to those of herbicide-resistant crops and Arabidopsis described above.

In this paper we found double mutations in the ALS gene of BS-resistant rice cells, which resulted in W548L/S627I mutations in its amino acid sequence. These mutations are a new combination of spontaneous mutations with a novel substitution at the S627 position. This ALS showed resistance to different classes of ALS-inhibiting herbicides, but showed the highest resistance to BS. The resistant level of the ALS to BS was extremely high as compared with those to SUs and IMs. Co-existence of W548L and S627I mutations resulted in synergistic resistance to BS, which could not be predicted from either W548L or S627I mutation alone. Such an effect was not, however, observed in the inhibition by CS. Transformed rice cells with the W548L/S627I double-mutated ALS gene grew normally in the presence of BS and the regenerated plant expressed resistance to BS, indicating that the mutated ALS gene works functionally in the plant when introduced by genetic engineering. This result showed the mutated ALS gene obtained here could be used as a selectable marker gene along with BS for genetic transformation of plants.

The FAO/WHO expert panels encourage the use of recombinant DNA without antibiotic-resistant marker genes, particularly those that could interfere with human and animal therapies, ${ }^{25)}$ and the scientific panels on genetically modified organisms of the European Food Safety Authority have categorized antibiotic-resistant marker genes into three groups, ${ }^{26)}$ one of which includes the neomycine phosphotransferase gene (NPT II, a kanamycin resistant gene $)^{27)}$ and the hygromycine phosphotransferase gene (HPT, a hygromycin resistant gene), ${ }^{28)}$ where the use of genes is not prohibited either for field experiment of transgenic plants or for the purpose of placing plants on the market, but in the other two groups including other antibiotic-resistant genes, it is prohibited to use the genes in transgenic plants for marketing. Furthermore, the Codex guideline recommends that alternative transformation technologies that do not result in antibiotic-resistant marker genes in foods should be used in the future development of recombinant-DNA plants. ${ }^{29}$ Therefore, the double-mutated ALS gene from rice is not only helpful for introducing useful rice genes into rice by self-cloning as a host-derived selectable marker gene but also can extinguish the scientific concern for antibiotic-resistant genes, leading to minimize public concern for this issue in transgenic plants. It is expected that this gene will be used widely together with PC herbicides, especially BS, as a selectable marker for plant genetic transformation in general. This gene is assumed to be safe to use because it has been isolated from BS-resistant rice cells that were spontaneously mutated through co-cultivation with BS.

\section{Acknowledgements}

This research was supported by a grant from the Ministry of Agriculture, Forestry, and Fisheries of Japan, whose title was Integrated Research Program for the Development of Novel Weed Control Technology by Applying Metabolic Genes in Plants.

\section{References}

1) T. Shimizu, I. Nakayama, K. Nagayama, T. Miyazawa and Y. Nezu: "Herbicide Classes in Developement: Mode of ActionTargets-Genetic Engineering - Chemistry" ed. by P. Böger, K. Wakabayashi and K. Hirai, Springer-Verlag, Berlin Heidelberg, pp. 1-41, 2002.

2) K. Y. Lee, J. Tepperman, M. Black, C. F. Chui, B. Mazur, P. Dunsmuir and J. Bedbrook: EMBO J. 7, 1241-1248 (1988).

3) R. G. Duggleby and S. S. Pang: J. Biochem. Mol. Biol. 33, 1-36 (2000).

4) H. P Hershey, L. J Schwartz, J. P Gale and L. M. Abell: Plant Mol. Biol. 40, 795-806 (1999).

5) Z. Li, A. Hayashimoto and N. Murai: Plant Physiol. 100, 662-668 (1992)

6) H. Uchiyama and T. Murashige: Plant Physiol. 54, 936-944 (1974).

7) M.-W. Kil and S.-I. Chang: J. Biochem. Mol. Biol. 31, 287-295 (1998).

8) I. Mitsuhara, M. Ugaki, H. Hirochika, M. Ohshima, T. Murakami, Y. Gotoh, Y. Katayose, S. Nakamura, R. Honkura, S. Nishimiya, K. Ueno, A. Mochizuki, H. Tanimoto, H. Tsugawa, Y. Otsuki and Y. Ohashi: Plant Cell Physiol. 37, 49-59 (1996).

9) L. Y. Fang, P. R. Gross, C. H Chen and M. Lillis: Plant Mol. Biol. 18, 1185-1187 (1992).

10) T. Shimizu: J. Pestic. Sci. 22, 245-256 (1997).

11) P. Bernasconi, A. R. Woodworth, B. A. Rosen, M. V Subramanian and D. L. Siehl : J. Biol. Chem. 270, 17381-17385 (1995); Correction, J. Biol. Chem. 271, 13925-13926 (1996).

12) J. Hattori, D. Brown, G. Mourad, H. Labbe, T. Ouellet, G. Sunohara, R. Rutledge, J. King and B. Miki: Mol. Gen. Genet. 246, 419-425 (1995).

13) J. M. Hand, B. K. Singh and R. S. Chaleff (American Cyanamid Company): Eur. Pat. Appl. EP 492113 (1992).

14) K. Rajasekaran, J. W. Grula and D. M. Anderson: Plant Sci. 119, 115-124 (1996).

15) G. W. Haughn and C. R. Somerville: Plant Physiol. 92, 1081-1085 (1990). 
16) G. Mourad and J. King: Planta 188, 491-497 (1992).

17) S. Bright, J. William, M. T. Chang, I. J. Evans and M. J. Macdonald (Imperial Chemical Industries PLC): PCT Int. Appl. WO 9208794 (1992).

18) G. E. Dietrich (American Cyanamid Company): US Pat. Appl. US 5731180 (1998).

19) Y. T. Lee, L. A. Chang and R. G. Duggleby: FEBS Lett. 452, 341-345 (1999).

20) J. Hattori, R. Rutledge, H. Labbe, D. Brown, G. Sunohara and B. Miki: Mol. Gen. Genet. 232, 167-173 (1992).

21) G. Mourad, G. Haughn and J. King: Mol. Gen. Genet. 243, 178-184 (1994).

22) T. R. Wright, N. F. Bascomb, D. Penner and S. F. Sturner: Weed Sci. 46, 13-23 (1998).
23) C. Chom-Kyu and C. Jung-Do: Biochem. Biophys. Res. Commun. 279, 462-467 (2000).

24) L. L. Saari, J. C. Cotterman and D. C. Thill: "Herbicide Resistance in Plants Biology and Biochemistry," ed. by S. B. Powles and J. A. M. Haltum, CRC Press Boca Raton, FL, pp. 83-139, 1994.

25) http://www.who.int/foodsafety/biotech/who_study/en/index. html

26) http://www.efsa.eu.int

27) J. Velten, L. Velten, R. Hain and J. Schell: EMBO J. 3, 2723-2730 (1984).

28) L. Gritz and J. Davies: Gene (Amsterdam), 25 179-188 (1983).

29) http://www.codexalimentarius.net/web/standard_list.do?lang= en 